\title{
Development of Personal Income Taxation Achievement by Practicing Skills within the Class in the Course of Tax Law
}

\author{
Pornpen Traiphong ${ }^{1}$, Nawarat Chowanachote ${ }^{2}$, Warunya Somsiri ${ }^{3}$, Kasidech Sutthivanich ${ }^{4}$ \\ ${ }^{1}$ School of Law and Politics, Suan Dusit University. \\ ${ }^{2,3,4}$ Faculty of Business Administration, Rajamangala University of Technology Phra Nakhon. \\ Email: ${ }^{1}$ cherrypornpen@yahoo.com, ${ }^{2}$ Nawarat.c@rmutp.ac.th, ${ }^{3}$ warunya.so@ rmutp.ac.th, ${ }^{4}$ kasidech.s@rmutp.ac.th.
}

\begin{abstract}
This academic article presents the principles of teaching and learning to promote proactive learning or active learning. Action by focusing on learning is important, and also using the proactive learning management process. The use of learning through the use of practicing skills within the class. The goal of teaching and learning management that focuses on the students is to manage learners to create new knowledge through self-thinking process, allowing the learner to learn by doing, and to understand. It can bring knowledge to integrate into daily life and have qualifications for the goals of education that want learners to be smart, good and happy. Good teaching is a dynamic movement, constantly changing, both in organizing activities and teaching method which consists of creating atmosphere, technique, style, content, and things that are not too far from the students and planning of teaching and learning systematically.
\end{abstract}

Keywords

Achievement, Personal Income Taxation, Practicing Skills

Article Received: 10 August 2020, Revised: 25 October 2020, Accepted: 18 November 2020

\section{Introduction}

National Education Act 1999, Section 22 states that the provision of education must be based on the principle that all learners have the ability to learn and develop themselves, and that learners are of the most importance in academic learning. On the legal side must have good knowledge, skills and attitudes in the legal profession. At present, the business industry has expanded more. Taxation is more important. Coupled with the economic situation and the trade of the country has evolved rapidly. The importance of taxation information requires accuracy, certainty and reliability.

All educational institutions would like to have education management to be effective and meet the goals according to the vision mission of each place by establishing strategies for developing the process for selecting learners with potential. The teaching and learning management according to the National Education Act 1999 has focused on the learners most important. All learners have the ability to learn and develop themselves. In the management of education, it is necessary to encourage learners to develop themselves to their full potential. Therefore, in the management of teaching, there must be a variety of forms to meet the needs of individual learners. The instructor must give the learner the greatest care. By studying the teaching methods and learning methods of learners in new ways to be used in solving problems or developing learners. With a focus on teaching instructors to integrate research processes or integrate them into learning development [1]

From observing teaching and learning in the subject of tax law on personal income tax for the 4th year students in the Bachelor of Laws program, it was found that students could not distinguish the type of tax in the personal income tax and calculation error. The main item relating to the calculation of personal income tax must be able to classify the individual income and deduct the deductible correctly. From the teaching results of the students in the aforementioned law programs Found that students studying tax law only 20 percent of which can calculate personal income tax correctly, the other 80 percent do not understand the principles of personal income tax calculation. Relying solely on memorization and do not understand about calculating personal income tax. When analyzing the main causes of teaching and learning, it was found that the students' failure to prepare the exercises by themselves. Caused by the students do not understand it. Because the students will not seek help with classmates in matters they do not yet understand. Fear of friends to insult and it is also important to note that once each day of study is complete, students will hurry home. It may cause students to incorrectly calculate personal income tax, which is a reason for confusion. If it still going on or has not been resolved it will cause an impact on academic achievement will lead to a bad attitude towards continuing to study tax law.

Therefore, the instructor decided to solve the problem for students to have the skills to calculate the personal income tax correctly. Using the personal income tax calculation skill form to develop students to know the process of calculating personal income tax on personal income tax in Tax Law.

The Bachelor of Laws program recognizes the great importance and necessity of tax law. This is a course that focuses on the importance of students to increase their potential to be efficient and effective by studying the principles of taxation in respect of income tax from the Revenue Code, for example personal income tax. Corporate income tax VAT Specific business tax And stamp duty. Which will enable learners to apply their knowledge and ability to apply in daily life and professional practice in order to develop the potential of the lecturers of the Bachelor of Laws to international. This is in line with [2] research on the expectation of Bachelor of Law students in teaching English for lawyers The key findings of this study are that students have high overall and individual expectations for teaching English for Law. In particular, the 
instructors' teaching expectations were at the highest level. And the instructors should understand and recognize the importance of students' basics in English. For the achievement of teaching and learning that will make the students learn real benefits.

Teaching this subject in tax law the instructor has organized a student-centered instruction. In order for learners to create new knowledge through the self-thinking process. Which allows the learner to learn by doing understand and can bring knowledge to integrate into daily life. Have qualifications for the goals of education that want learners to be smart, good and happy. Instructors therefore take into account various issues in organizing teaching and learning activities. Individual differences of learners focusing on the needs of the learners improving the quality of life of the learners activities to be interesting does not make the students feel bored kindness to learners challenging the learner to know recognizing the right time for learners to learn creating an atmosphere or situation for learners to learn by doing. Support and promote learning teaching aim learners understanding learner background not sticking to one particular method teaching good is dynamic, that is, the movement is constantly changing in terms of activities. Atmosphere creation Form, content, techniques, methods of teaching things that are not too far from the learner And teaching and teaching planning systematically by definition of academic achievement (Achievement) at [3] has defined the achievement as it is learning according to a predetermined plan. Arising from the teaching and learning process during a particular period of time which find [4] meaning that the measure of academic achievement is a measure of academic success. Or measure the learning experience that students gain from teaching and learning. It is measured according to the aim of teaching or to measure the achievement of the education and training programs. This is consistent with [5] defining academic achievement as attributes, including knowledge. The competence of the individual as a result of the teaching or the mass experience that the individual gains from teaching Causing individuals to change behavior in different areas of brain function Which is intended to check the level of brain competence of a person that learns what And what kind of ability. As well as the consequences of learning, training or experiences in school, at home and in other environments, including feelings, values and ethics are the result of practice. From this definition Academic achievement is the learning outcome according to the course Acquired according to the measurement and evaluation principles covering both cognitive and cognitive aspects emotional and emotional or spiritual aspects and the skill, practice, or character skill set by the instructor at a particular time. In general, the measure of academic achievement will measure knowledge and abilities according to the subject matter studied which is mostly cognitive or cognitive Most of the tools used to measure the test are called the achievement test. The objective is to know that the learner after the teaching and learning process will have the knowledge level. So that instructors can find a way to improve, correct, develop and encourage learners to develop their knowledge to their full potential. But to create a quality test the instructor must have knowledge of the nature of the test. Planning, creating principles, creating a selection of test types to suit the content; and use of exam results to improve and summarize grades

\section{Meaning of achievement test}

The word the achievement test has many interested people to study the meaning and say it. Achievement tests mean that the achievement test is a test used to measure the brain behavior of the learners having knowledge and ability in the subject they have learned. Or how much has been trained? [1] [6] said that the learning achievement test was a test that measures knowledge, skills, and academic ability that the learner has learned how accomplished the stated purpose. So it can be concluded that Academic achievement test is a test used to measure knowledge and skills learned from the past or in the present state of the individual. However [7] said achievement means success, fluency. Proficiency in the use of skills or the application of knowledge, the achievement refers to the knowledge or skills that arise from learning in the subjects that have been learned. This is obtained from the results of the instructor test or the person responsible for teaching or both.

From the above, it can be concluded that academic achievement is the learning outcome according to the course which has been applied in accordance with the measurement and evaluation principles covering both knowledge thought or cognition emotional and emotional or psychological aspects and the skill, practice, or skill set by the instructor during the period of instruction.

\section{Types of tests}

There are two types of achievement tests: instructor made tests and standardized tests. Both of which ask for the same content. It was asked what the learners had received from the teaching which could group 6 types of behaviors: knowledge, memory, comprehension, application, analysis, synthesis and assessment. [5]

1) Instructor-created quizzes are self-created quizzes to test students in a classroom.

1.1 Objective tests such as True-false, Matching, Completion or Short answer and multiple choice.

1.2 Essay tests, for example restricted response items and Extended response items.

2) Standardized test are tests that produce by experts with knowledge of the content and have test-making skills there is an analysis of the quality of the test. There is a clarification on the examination. Grading and Interpretation. There is multiple choice (Objective) accuracy (Validity) and confidence. (Reliability) Standardized tests include the California Achievement Test, the Iowa Test of Basic Skills, Standford Achievement Test, and the Metropolitan Achievement tests. 


\section{Types of achievement tests}

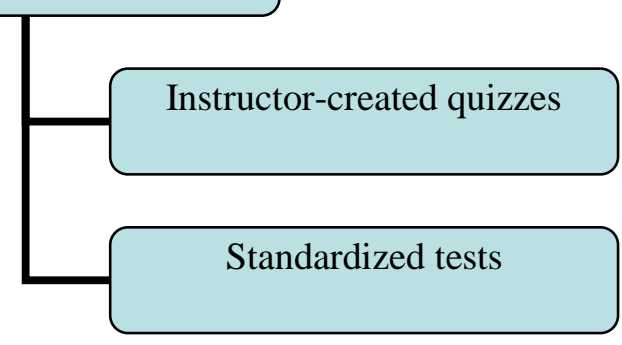

Fig. 1 Types of achievement tests

For [8], the test was classified into 3 types as follows:

1) The oral version is a test that relies on individual questioning. It works well if a small number of people take the exam. Because it takes a lot of time can ask carefully because they can interact with each other

2) The written answer is a test that is changed from the oral exam. Due to the large number of people who take the exam and the number is limited, it can be divided into 2 types:

(1) Essay or subjective is an exam that allows respondents to independently compile their own words in expressing attitudes, feelings and thoughts under a given subject. Is an exam that can Good measure of synthesis behavior but there is a downside to the rating. Which may not be accurate making it difficult to have multiple choice.

(2) Answer limit it is an exam that has correct answers under limited conditions. This type of test is divided into 4 types: correct, wrong, additive, matching and multiple choice.

3) Practice exercise is a test in which the test taker demonstrates the behavior by actual action or practice, such as a musical test, mechanic, physical education, etc.

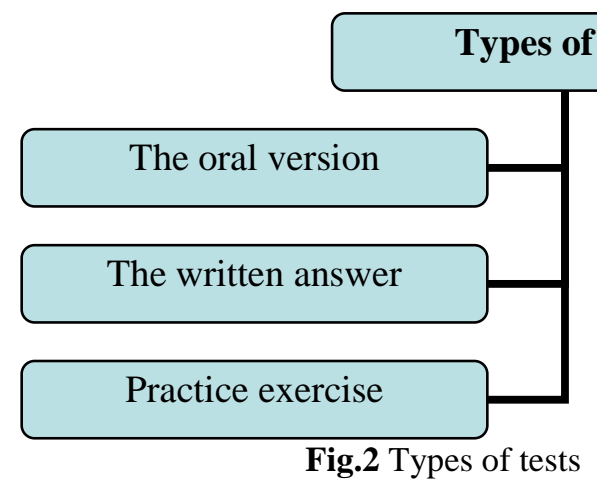

It can be concluded that the academic achievement test can be divided into two types: standardized test. Which is built by experts in content and educational measurement there is a good quality search. The other type is instructor-created quizzes. For use in classroom testing in designing, testing, measuring academic achievement, vocabulary for communication. The instructor has chosen a researcher-built practice test to measure vocabulary ability to be used in oral and written communication and choose a written quiz that limits answers by selecting answers from the given options. In creating quizzes to cover content and measure behaviors that are appropriate to the content. Developing the table of specifications should be created to guide the building, just like building a house drawing. Also known as a Test blueprint, the curriculum analyzes the curriculum topic. And learning objectives and desired behaviors to be measured.

Creating a Tables Analysis Course starts with creating a 2D table, ie vertical, the behaviors that need to be measured including memory, understanding, application, analysis, synthesis and valuation the horizontal section is for the topic, content or learning objective. Which depends on the subject matter and / or objectives. Then determine the weight of the content. Consider the importance of the content which may define the weight in percent Along with determining the behaviors that need to be measured and set the importance By considering the learning purpose along with the content Finally, the test to be measured, such as correct, wrong, match, add-on, choice or subjective, etc.

\section{The benefits of skill exercises}

The benefits and importance of skill exercises. [9]

1. Make students better understand the lessons.

2. Make the instructors know the understanding of students towards learning.

3. Helps instructors improve teaching content and activities in each lesson.

4. Help children to learn better according to their abilities.

5. Train students to have confidence and be able to assess their work.

6. Train students to work sequentially with responsibility for the assignments.

Where [10] said that the benefits of the skill training are as follows:

1. As an additional or supplement to textbooks for skills training

2. Helps to enhance the use of skills.

3. It helps with individual differences.

4. Helps to strengthen the lasting skills by practicing immediately after learning the subject, repeat many times. The practice should focus on the subject that was practiced. In the section [11], the benefits of skill training are described as follows.

1. It is a device to help reduce the burden of instructors.

2. Help students to improve their skills.

3. It helps with individual differences. Causing students to achieve great mental results

4. Helps to strengthen skills in durability

5. It is a tool to measure grades after learning the lesson.

6. Help students to review lessons by themselves.

7. Help instructors look into problems. Of students clear

8. Allowing students to practice fully In addition to what was learned in the lesson

9. Help learners see their own progress.

However, [12] mentioned the benefits of the skill training as follows:

1. To enhance skills Practice exercises are tools that assist students in practicing their skills, but they require encouragement and attention from their instructors.

2. Helps in the differences between people. Because students have the ability Different language Allowing students to do exercises that are appropriate for their abilities will help students achieve more mental achievement. Therefore, exercise is not a workbook. The more the instructor gives to the students. Chapter by chapter or page by page. 
3. It is a unique source of experience for students who need extra help. And it is a valuable aid to instructors to meet the individual needs of the class.

4. Practice exercises help to build lasting skills. The characteristics of training to help achieve this effect are:

4.1 Practice immediately after the student has learned the subject repeatedly.

4.2 Focus only on wrong matters

5. The exercises used will be a tool to measure learning achievement after each lesson.

6. Exercises that are created as a booklet, students can be kept for use as a guide. For further self-review.

7. Having students complete the exercises helps instructors to clearly see the student's hot spots or problems. This will help instructors to improve and solve the problem promptly. 8. Exercises held other than those contained in the textbook. It will help students to practice fully.

9. The training has already been printed. This will help instructors save both labor and time. In order to always be prepared to create a practice. For the learners, there is no need to spend time copying the practice from textbooks or blackboards. This gives them more time and opportunities to practice various skills.

10. The exercise style saves money. Because the publication is a certain format. It is not necessary to invest less than to use the printing method on wax paper every time. And see their progress in a systematic and orderly manner.

\section{The meaning of Practicing}

The person who proposed this meaning is [13], who has proposed the meaning of Practicing as follows.

Practicing is the repeated act of behavior that has been learned in order to develop a skill or expertise or a habit, for example when learning mathematical principles or theories. Science already it has to be practiced by doing the exercises, etc. and in the practice should follow the following principles.

1. Begin training when students are ready first.

2. Should take into account the difficulty of the things to be practiced.

3. Define the training period appropriately, not too long or too long.

4. If there is a lot of practice must be divided into periods

5. Students should know the progress in the practice.

\section{The good nature of a good skill exercise}

By creating a practice exercise to train analytical skills to achieve that objective requires a variety of forms of training. This must be consistent and appropriate for the skills to be practiced. The concept of characteristics and patterns of good skill training which [14] has proposed, the characteristics of a good practice should look like this:

1. Relate to the story that has been learned

2. Suitable for the class level or the age of the students

3. There is a short statement to understand.

4. Use the right time.

5. There are interesting and challenging things to show your abilities.

6. Should have instructions for use.

7. There are limited choices and free answers.
8. If it is a practice that requires students to study by themselves the exercise should be multiple forms.

However, [15] has proposed the following characteristics of a good training model.

1. It should be created to practice what it is teaching. Not a test that students what did you learn?

2. Should be about the structure of what is taught alone.

3. What you practice is what students have already seen.

4. Should be a short message.

5. Do not use too many words.

6. Should be a practice that encourages the child to respond to the desires.

Where [16] said that a good practice should consist of

1. Contain content that matches the purpose

2. Activities suitable for age level or the ability of students

3. The illustrations are well laid out.

4. Spend time appropriate for training.

5. Challenge students' abilities and be able to practice by themselves.

However, [17] said that the instructor or the person creating the exercise should adhere to the following characteristics of good practice.

1. Good exercises should be clear in both instructions and how to do them. The instructions or examples showing the actions used should not be too long. Because it will make it difficult to understand. It should be adjusted to be easy and suitable for the user so that students can study by themselves if desired.

2. Good exercises should be meaningful to learners and meet the purpose of the practice. Little investment, can be used for a long time and be up to date on a regular basis.

3. The language and images used in the exercises should be appropriate for the age and knowledge base of the learners.

4. Good exercises should be separate, individual topics should not be too long. But there should be a variety of activities to stimulate students' interest. And not boring in doing and to practice any skill until mastery.

5. Good exercises should include both the fixed-answer and the free answer. Choosing to use words, texts or pictures in exercises. It should be something that students are familiar with and meet their interests. This is so that the exercises are created to be enjoyable and pleasurable for the user, which is in line with the learning principle that students tend to learn quickly in satisfying actions.

6. Good exercises should give students the opportunity to study by themselves, to learn, to research, to collect common things that they have seen or used themselves. This will enable the students to understand the subject better and will be able to apply that knowledge in their daily life properly and properly. And see that what students practice is meaningful and beneficial to students forever in the future.

7. Good exercises should cater to different students' individual differences. They differ in many areas, such as needs, attention, readiness, intelligence level. And experience, etc. Therefore, each exercise should be sufficiently prepared and available at all levels, from easy to medium to relatively difficult. So that both students are good, middle and weak, can do according to ability. This is for every student to be successful in completing the exercise.

8. Good exercises should be able to excite students' attention from the cover to the last. 
9. Good exercises should also be exercises that can be assessed and classified by students.

From studying the characteristics of good training enough to conclude that good exercises should include psychology, proper linguistics, fun practice, awakening interest and meaning in life. Suitable for age and ability and may be able to study by themselves, which the report can be considered as a guideline for preparing the exercise to suit the age Student abilities several elements match the content. Appropriate to the age, time, ability, attention and problem of the learners.

\section{A good practice component}

The components of a good exercise should include the following documents. [14]

1. Practice Manual It is an important document for the practice of what it is used for and how to use it. Used for home use, repairing, which should consist of

1.1 Components of the exercise how many sets are indicated in this exercise? What and whether there are other components, such as a test or an assessment record.

1.2 What instructors or students must prepare It will tell instructors or students to prepare in advance.

1.3 Purpose of using exercises

1.4 The steps for using each item are listed in order of use and may be written in the form of teaching or lesson plans to be more clear.

1.5 Answers to practice exercises in each set.

2. Practice is a media created for students to practice skills for permanent learning.

2.1 Name of training set in each sub-set

2.2 Purpose

2.3 Instruction

2.4 Example

2.5 Practice sets

2.6 Illustration

2.7 Pre-study test - after study

2.8 Use evaluation form.

In the importance of the exercise, good exercises are essential to improve learners' skills and are an integral part of the Primary Education Curriculum, Year 2521 (Revised Edition 2533) [18] in line with [19] said that exercises are very necessary. Instructors must provide appropriate exercises in order to practice after having learned the content from the textbooks to have extensive knowledge. It can be considered that exercises is one of the teaching materials. Which instructors are able to use in teaching activities very well and helping instructors to teach success and in line with [17] also said that Work book is a teaching medium that is prepared. This is to enable learners to study, understand and practice until they come up with correct concepts and skills in a particular subject. Moreover, the exercises are also used to indicate that the learner or the user of the exercise has knowledge of the lesson and is able to how much of that knowledge can be used Learners have strengths that should be promoted or have weaknesses that need to be improved, where and how good and complete exercises. Therefore, it may be used as a substitute for a diagnostic test for assessing student progress. Exercises can be considered an important tool that all instructors use to examine their cognition and develop students' skills in a range of subjects. Appropriate exercises for each age student contribute to student success. Creating pride that brings joy and pleasure in doing. There is an opportunity to use imagination to develop creativity. On the body side, it will lead to the development of the muscles and the senses from the practice of writing hand gestures, hand gestures.

\section{Personal income tax}

Personal income tax is tax levied on individuals. Or from a special taxation unit as required by law and generate income according to the specified criteria usually stored annually Income generated in any year income earners are obliged to present themselves on the required tax return by January to March of the following year. For some income earners, the law also requires the filing of the form. Tax payable at half year on actual income in the first half of the year. In order to relieve the tax burden that must be paid and in some cases the law requires that the payer acts withholding tax on part of the income paid. So that there is a gradual tax payment while there is income arising as well.

Persons liable to personal income tax are those whose income arising during the past year with One of the following (Section 56 and Section 57) as follows:

1. Natural person.

2. Non-juristic partnership.

3. Those who died during the tax year.

4. The estate that has not yet divided.

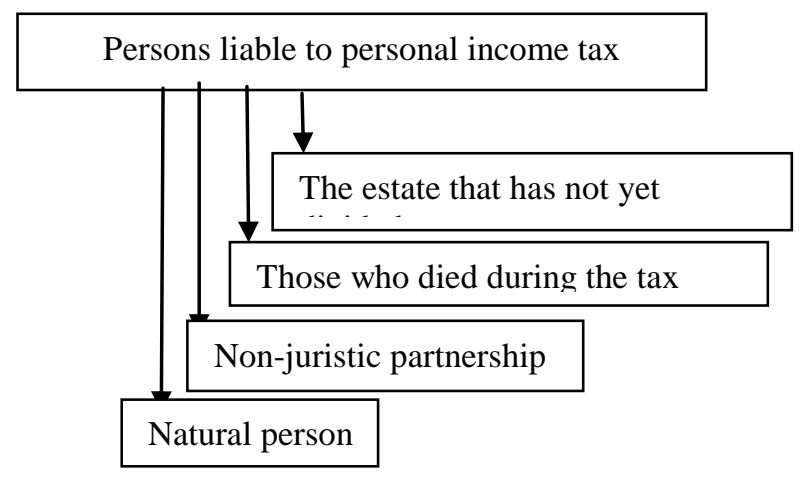

Fig.3 Persons liable to personal income tax

Assessable income is income of the following categories.

1. Income derived from employment, whether in the form of salary, wage, per diem, bonus, bounty, gratuity, pension, house rent allowance, monetary value of rent-free residence provided by an employer, payment of debt liability of an employee made by an employer, or any money, property or benefit derived from employment

2. Income derived from a post or from performance of work, whether in the form of fee, commission, discount, subsidy, meeting allowance, gratuity, bonus, house rent allowance, monetary value of rent-free residence provided by a payer of income, payment of debt liability of a taxpayer made by a payer of income, or any money, property or benefit derived from a post or from performance of work, whether such post or performance of work is permanent or temporary.

3. Fee of goodwill, copyright or any other rights, annuity or annual payment of income derived from a will, any other juristic act, or court decision.

4. Income that is: 
(a) Interest on a bond, deposit, debenture, bill, loan whether with or without security, the part of interest on loan after deduction of withholding tax under the law governing petroleum income tax, or the difference between the redemption value and the selling price of a bill or a debt instrument issued by a company or juristic partnership or by any other juristic person and sold for the first time at a price below its redemption value. Such income also includes income assimilated to interest, benefit or other consideration derived from the provision of a loan or from a debt-claim of every kind whether with or without security.

(b) Dividend, share of profits or any other gain derived from a company or juristic partnership, a mutual fund or a financial institution established under a specific law in Thailand for the purpose of providing a loan in order to promote agriculture, commerce or industry; the part of dividend or share of profits after deduction of withholding tax under the law governing petroleum income tax.

For the purpose of income calculation under paragraph 1, if a lawful child who is a minor derives income and the marital status of the parents exists throughout the tax year, the income of the child shall be treated as income of the father. However, if the marital status of the parents does not exist throughout tax year, the income of the child shall be treated as income of the parent who exercises parental power, or of the father if both parents jointly exercise parental power.

The provisions of paragraph 2 shall apply mutatis mutandis to an adopted child who is a minor deriving income.

(c) Bonus paid to a shareholder or partner of a company or juristic partnership;

(d) A decrease of the capital holdings in a company or juristic partnership which does not exceed the total amount of profits and reserves;

(e) An increase of capital holdings in a company or juristic partnership that is determined from the total amount of profits or reserves;

(f) A benefit derived from the amalgamation, acquisition or dissolution of a company or juristic partnership and having the monetary value which exceeds the capital;

(g) Gains derived from transfer of partnership holdings or shares, debentures, bonds, or bills or debt instruments issued by a company or juristic partnership or by any other juristic person.

5. Money or any other gain derived from:

(a) Rent of property,

(b) Breach of a hire-purchase contract,

(c) Breach of an installment sale contract, where the seller regains the property sold without paying back the money or gains already received.

6. Income from liberal professions, namely, laws, arts of healing, engineering, architecture, accounting, fine arts or other liberal professions as prescribed by a Royal Decree;

7. Income derived from a contract of work where the contractor has to provide essential materials besides tools; 8. Income from business, commerce, agriculture, industry, transport or any other activity not specified in (1) - (7).

Categories of assessable income

1. Income derived from employment aucallon.net

\section{Fig.4 Categories of assessable income}

\section{Related research}

It is very important for instructors to acquire knowledge in creating training exercises that will train students' skills to create such exercises as highly effective and suitable for the students. With [20] doing research on Using the skill training On account recording according to the dual accounting system In the financial accounting course For students in the Accounting Division, Vocational Certificate 1, Lanna Polytechnic College of Technology, Chiang Mai, found that students had higher academic achievement in line with the [21] conducting research on Using a skill set to solve the problem of students' lack of skills in recording trade in general ledger Of vocational students in Vocational Year 1/7 of Rayong Commercial School, the first semester of the 2007 academic year, totaled 12 students, found that the students had higher academic achievement and passed the assessment criteria for everyone Creation and development of a practice for enhancing cost accounting skills 1 for vocational students level 1 in accounting Roi Et Vocational College, 38 people. It was found that 30 students from a total of 38 students, representing 81.08 percent, received an examination score of more than 50 percent, and the results of absenteeism after 35 students passed the test, representing 91.89 percent who did not pass the test. 8.11 percent of people. And [22] conducts research on the development of academic achievement in introductory accounting for 2 subjects, recording transactions in general journals of Vocational 1/4 students using the skill training form, Srithana Commercial College 
of Technology, Chiang Mai, 20 people found. That students have higher academic achievement And pass all criteria.

From the study of related research making it possible to conclude that using the Pre-School and Post-Study Skill Training Set, you can see how you improve your students. And can do exercises correctly.

\section{Conclusion}

Using the Pre-School and Post-Study Skill Practice Set, students will be able to learn about the content and practice doing a practice exercise at the same time. Make students better understand the content and be able to practice the skills properly. The skills training appropriate for each age student contributes to the success of the teaching and learning process to the success of the course.

\section{References}

[1] S. Tanya, Educational Evaluation, Bangkok, Suwariasan, 2002.

[2] P. Traiphong, Achievement of Learning English Vocabulary about Criminal Law and Criminal Procedure from Playing Kahoot Game of Law Students, Phranakhon Rajabhat Research Journal Humanities and Social Sciences Year 14, Issue 2, July - December 2019, 2019.

[3] S Kanjanawasee, Traditional test theory, 4th edition, Bangkok, Chulalongkorn University, 2001.

[4] Sukhothai Thammathirat Open University, Theory and Practice in Educational Administration Unit 9-12, 4th edition, Bangkok, Sukhothai Thammathirat Open University Press, 2003.

[5] P. Khachen, (KU), Measuring achievement in learning from www.wattoongpel.com Sarawichakarn / wichakarn / 1-10, Measurement of academic achievement 10.pdf, 2013.

[6] P. RitJaroon, Research for learning development, classroom research practice, (3rd edition)., Bangkok, Education, Phranakhon Rajabhat University, 2002.

[7] P. Duangnet, Factors Relating to the Academic Achievement of Intermediate Accounting 2 of the 2nd year undergraduate students, Faculty of
Accounting, Sripatum Bangkhen University, 2009.

[8] P. Taweerat, Methods of behavioral science and social science, (7th edition) Bangkok, Office of Educational and Psychological Testing Maha Vatiyalai Srinakarinwirot, 2000.

[9] R. Sripraiwan, Practice Thai language skills for first-class children, In the handbook, some ideas and perspectives on tactics and teaching children begin to learn to speak bilingual, Nakhon Ratchasima, Office of the Education Area 1, 1974.

[10] Y. Yimphong, Creating a practice writing of words using the letter "R", "L" and "W" for grade 4 students, Nipon Ph.D., Master of Arts in Thai Language Teaching Graduate school Kasetsart University, 1979.

[11] P Sangsukpeam, Thai language teaching behavior Elementary level "Theory and Practice", Bangkok, Odeon Street, 1995.

[12] P. Minsen, Development of teaching and learning activities, Mathematics Skill Group Using teaching materials Udon Thani, Chum Saeng Municipality Education Division Municipal School 3 (Wat Saengtham Suttharam), 2006.

[13] S. Suthelert Arun, Philosophy and Morality for Instructors. Bangkok, Bundit Printing Press, 1983.

[14] K. Saengdet, Practice, Bangkok, Mac Publishing House, 2002.

[15] S. Chaisakul, The creation of a pronunciation practice for the mother's spelled words "Kok", "Press" and "Frog" for Malay-speaking students, Primary Level 5, Yala Province, Witthaya Nopon Bachelor of Arts, Major Education Program Graduate school Kasetsart University, 1983.

[16] K. Mahapho, Research report on the comparison of students' spelling writing results. Grade 3 in the district Primary Education Office, Udon Thani Province Using practice spelling and dictation, Udon Thani, Communication Study Unit 
District Primary Education Office Udon Thani Province, 1992.

[17] W. Bunwiroj, Development of mathematical skills at the elementary level, Known stories for math instructors, 2nd edition, Bangkok, Thai Wattana Panich, 1993.

[18] Department of Academic Affairs, Manual of Primary Education Program 1978, Bangkok, United Productions, 1979.

[19] S. Suthiphet, Practice for teaching phrases in Thai at the level of academic education certificate, Faculty of Science, Bangkok, Chulalongkorn University, 1984.

[20] C. Boonmee, Use of skill enhancement exercises, On account recording according to the dual accounting system in the financial accounting course Lanna Polytechnic Technology College, Chiang Mai, 2011.

[21] S. Sida, The use of a skill set to solve the problem of student lacking skills in recording trade transactions in general ledger Rayong Commercial School, 2008.

[22] S. Chaichana, Development of academic achievement in introductory accounting subjects, recording transactions in general journal Using skill exercises Chiang Mai, Srithana Commercial Technology College, 2011. 